NBER WORKING PAPERS SERTES

\title{
CAREER PLANS AND EXPECTATIONS OF YOUNG \\ WOMEN AND MEN: THE EARNINGS GAP \\ AND IABOR FORCE PARTICIPATTON
}

Francine D. Blau

Marianne A. Ferber

Working Paper No. 3445

NATIONAL BUREAU OF ECONOMIC RESEARCH 1050 Massachusetts Avenue

Cambridge, MA 02138

September 1990

Francine Blau is Professor of Economics and Labor and Industrial Relations at the University of Illinois, Urbana-Champaign, and Reseanch Associate of the National Bureau of Economic Research. Marianne Ferber is Professor of Econcmics at the University of Illinois, Urbana-champaign. We are indebted to the Graduate Research Board and the College of Commerce and Business Administration (CBA) Placement office of the University of Illinois, UrbanaChampaign for financial assistance, and the CBA Dean of Students office for their generous help with data collection. We are grateful for the helpful comments of Marlene Kim and case Sprenkle. Thanks are due to Jin-Hwa Jung and Paul Straub for able research assistance. This paper is part of NBER's research program in Labor Studies. Any opinions expressed are those of the authors and not those of the National Bureau of Econamic Research. 
NBER Working Paper \#3445

September 1990

\section{CAREKR PLANS AND EXPECIATIONS OF YOUNG WOMEN AND MFN : \\ THE EARNINGS GAP AND IABOR FORCE PARTICIPATION}

\section{ABSITRACT}

Using detailed information on the career plans and earnings expectations of college business school seniors, we test the hypothesis that wamen who plan to work intermittently choose jobs with lower rewards to work experience in return for lower penalties for labor force interruptions. We find that while men and women expect similar starting salaries, women anticipate considerably lower earnings in subsequent years, even under the assumption of contimuous employment after leaving school. While it is also true that women in the sample plan to work fewer years than men, these differences do not explain the observed gender differences in expected earnings profiles. We also find no evidence that gender differences in expected eamings have any effect on the number of years these women plan to be in the labor market.

Francine D. Blau Institute of Labor and Industrial Relations University of Illinois 504 East Anmory Averue Champaign, IL 61820

\author{
Marianne A. Ferber \\ Department of Econamics \\ University of Illinois \\ 1407 West Gregory Drive \\ Urbana, IL 61801
}


Though the male-female earnings gap has been declining in recent years, it remains quite substantial. Because regressions taking into account a wide variety of variables have falled to explain all of this gap, women's lower earnings are of ten in part ascribed to discrimination. Alternatively, it has been suggested that because women do not Intend to work continuously, they choose jobs requiring smaller investments in human capital, and hence with flatter lifetime earnings profiles. Previous research on this issue has not been conclusive, in part because it has generally been based on data describing outcomes, when evidence on plans and expectations is needed. A unique data set on college business school senfors, collected for this purpose, remedies this deficlency.

This paper begins with a brief review of explanations of the earn1ngs gap. The next section describes the data collection and the Information obtained for this study, followed by an examlnation of some of the interesting characteristics of the men and women in this ample. Finally, the evidence is analyzed and discussed and some conclusions and policy recommendations are offered.

\section{Explanations of the Male-Female Earnings Gap}

The human capital explanation for the earnings gap emphasizes women's weaker 1 abor force attachment as the major reason why they earn less than men (e.g., Mincer and Polachek, 1974; Polachek, 1975, 1981). I Its basic argument is as follows: It is assumed that women, unlike men, tend to work for pay intermittently because of household responsibilities, and the extent to which this is the case is largely 
exogenously determined. ${ }^{2}$ Hence, assuming that women and men have the same characteristics, each will, nonetheless, choose different jobs requiring different human captal investments. It is expected that the jobs selected by women will offer lower returns to experlence, but also carry smaller penalties for labor force 1nterruptions. Because women intend to spend substantial amounts of time out of the labor market, they are willing to accept lower rewards for experience in return for lower depreclation rates during perlods of work interruption. Consequently, the model predicts that women's earnings profiles w111 be flatter than those of men. Thus, all else equal, women are expected to have higher starting salaries, but after some minimal t1me, earnings will be higher for males than for females with the same level of experience. ${ }^{3}$ While the notion of "Job" in this model is often equated with "occupation," 1t could equally well be applied to career trajectories within occupations.

Additionally, it is often argued that women are at a disadvantage 1n career advancement because they do not have the same priorities. Due to the traditional division of labor in the family, women are belleved to seek jobs requiring less effort (Becker, 1985) ${ }^{4}$ and are thought to be less concerned with professional progress and intellectual challenges, more with comfort, flexible hours and a pleasant work environment (e.g., Applebaum and Koppel, 1978; Daysont and Andr1san1, 1988; Filer, 1985). These supply-side arguments complement the human captal model presented above.

A number of critics have taken 1ssue with this model (e.g., Corcoran, Duncan and Ponza, 1984; England, 1982), malnly on the ground 
that rates of depreciation and wage growth for women are simllar in male and female occupations, and that women with more continuous labor Force attachment do not tend to choose different jobs than other women. Such flndings ralse serlous doubts about an explanation of the earnings gap which relies so heavily on these differences in depreciation of wage rates during work interruptions and related differences in rewards for experience. 5 at the same time, this evidence is not conclusive.

As Gronau (1988, p. 280) points out, "Economic theory discusses the effect of planned (or future) career interruptions on current wages. Most emplefcal studies, however, examine the effect of past Interruptions." 6 Clearly, these are frequently not the same. ${ }^{7}$ Hence some women are likely to and up in jobs 111-sulted to maximizing their 1ifetime earnings, thus reducing the chances of finding the relationship predicted by the human capital model. These difficulties can be avolded by examining planned labor force participation and anticipated earnings. For it 18 expectations, whether or not they prove to be correct, that determine a person's cholces. In order to obtain this Information we conducted a survey of a group of young people who are ilkely to be very career orlented and hence have probably given more thought to job-related issues than most of thelr contemporaries. The chlef alternative explanation of women's lower earnings 18 that they are discriminated against (Becker, 1957). We offer no direct evidence on this point. However, lower anticlpated earnings for equaliy qualified women, regardless of their cause, are ilkely to Introduce feedback effects (e.g., Blau and Ferber, 1986; We1ss and 
Gronau, 1981). Thus women may plan to spend less time in the labor market, at least in part, because they expect lower rewards. Th1s in turn further depresses thelr earnings. Our data enable us to test this hypothesis by examining the effect of expected earnings on labor force participation plans.
\end{abstract}

\title{
Data Collection and Sample Description
}

Questionnalres were sent to al1 722 members of the 1987-88 sentor class in the College of Commerce and Business Administration (CBA) of the Unfversity of Illinols, Urbana-Champalgn. This group is particularly sultable for our purposes. Though they are not representative of the entire population, or even of all college students, the women in our sample are of interest because they are $11 k e l y$ to be representative of trends among recent cohorts who are spending increasingly more time in the labor market. Further, this is even more true of the college educated who are also increasingly moving 1nto previously male occupations. Another major advantage of this sample is that we have excellent controls for quality and type of education.

After two follow-up waves, responses were recelved from 227 of the 389 women, and 161 of the 333 men, not all of them entirely complete. Background Information for the sample is shown in Table $1 .^{8}$ Though the response rate was higher for women than for men, 58 percent as compared to 48 percent, for both sexes the respondents are reasonably representative of the whole class with respect to distribution by department and grade polnt average (GPA) (see Table A-1). 
Average grades are virtually the same for male and female respondents. There is, however, a substantial difference in their representation by department. Students in the College of Business Admin1stration may major in Accountancy, Business Administration, Finance, or Economics. The vast majority opt for the first three. 9 Among those, men are considerably less likely to be in Business Administration than women while the opposite is true of Finance and, to a lesser extent, Accountancy. The famlly backgrounds of the male and female students are in some respects quite similar. The parents of both groups are disproportionately in executive and professional occupations. However, women students are more likely than men to have mothers who are currently executives and professionals, and less likely to have mothers who are currently full-time homemakers. Their wothers had also spent a somewhat higher proportion of prior years in the labor force. This suggests that employed mothers, and especially those who pursue careers, provide the kind of role model that motivates daughters to go to college and choose career-orlented majors.

With respect to their own family plans, the vast majority of men and women plan to marry, however men intended to have somewhat more children than women. The expected number of chlldren for young women In this sample (2.4) is quite simlar to that reported by the Bureau of the Census (1988) for recent college graduates (2.2) and young managers and professionals $(2.1)$.

This information provides some insights about the sample we are dealing with. The remalnder of the questionnalre focuses on career plans and expectations. Table 2 shows some of the results. First, as 
is assumed by proponents of the human capltal explanation, men plan to work more years full-tlme and fewer years part-time, and are less likely to antlcipate droppling out of the labor force before retirement, though these differences are not as great as has actually been the case, even in relatively recent years. According to the Bureau of the Census (1987) employed women college graduates between ages 45 and 64 had spent, on average, 23 percent of potential work years away from work, compared to only 1 percent for men. The planned proportions for our sample are 14 percent for women and 4 percent for men, 1ncluding part-time employment. $^{10}$ It is also interesting that women in our sample plan to retire no earlier than men.

These differences may reflect the nature of our sample, college students in career-oriented flelds, and/or general increases in labor force attachment of women $1 \mathrm{n}$ younger cohorts (Sm1th and Ward, 1984). There 1s, in addition, a question as to whether women are actually likely to work as much as they plan to. Some evidence on this 1ssue 1s provided by Shaw and Shaplro (1987). Using data from the National Longltudinal study they found that young women who were between ages 14 and 24 in 1968 inftially substantially underestimated their future labor force particlpation at age 35, while their plans became more nearly realistic as they approached that age. There was no evidence of a tendency of young women to overestimate their future participation.

As would be expected on the basis of their majors, women and men selected somewhat different first cholces from among 10 occupations which, according to the CBA Placement office, comprise the great majorlty of those students from thls College actually take upon 
graduation. $^{11}$ A larger proportion of men opted for financial/credit analyst, and a somewhat larger proportion of women selected personnel/ labor relations specialist and marketing analyst. The differences otherwise are more modest, with slightly more men choosing accountancy, and an almost equal proportion of men and women choosing systems analyst, commerclal loan offlcer, and management tralnee, by far the most popular job.

Expected salaries by sex are shown in the bottom of Table 2 . Because of our interest in the determinants of expected earnings profiles for Jobs and in the effect of these profiles on labor force particlpation plans, we asked the students how much they would expect to earn Inftally and after 10 and 20 years $1 f$ they were to be cont1nuously employed in the1r preferred occupation after leaving school. As may be seen in the table, wen and women in the sample anticipate recelving very simllar salaries upon graduation--the fenale-male ratio 1897 percent. The differential in expected salaries, however, increases over time, with the ratio falling to 79 percent after 10 years and to 72 percent after 20 years. Thus women do anticipate flatter earnings profiles.

Table 3 presents female-male earnings ratios within occupations based on expected salaries in each student's top three cholces of occupations. ${ }^{12}$ with the exception of personnel and labor relations specialists and systems analysts, the fanning out of male and female expected salaries observed on the basis of overall averages occurs within each occupation as well, although not always to the 6 ame extent. Anticlpated salary differentals are particularly large for 
the managerial and $f$ inancial/credit analyst occupations which were the first cholce of 47.2 percent of the men and 41.5 percent of the women in our sample. The expected differentials are, however, in most cases somewhat smaller than actual differentials projected on the basis of 1980 age-earnings data for men and women. Thus, under the assumption of continuous employment, women in the sample do expect to do relatively better than women did in the past when many worked Intermittently. Nonetheless, these rather sizable anticipated differentials for continuous employment within occupations would superficlally appear to contradict the human capital explanation for gender differences based on the notion that women choose occupations with flatter profiles. It may be, however, that women and men select different detalled occupations or different career trajectories within these categories which require different levels of human capital investments. This 1ssue 1s 1nvestigated more systematically in regression analyses presented below which examine the impact of labor force participation plans on expected earnings profiles.

Last, we asked the students to choose the 3 most 1mportant and the 3 least 1mportant among 15 job characteristics 11sted. The results are shown in Table 4. In general, there are striking similarities between the prioritles of women and men, as well as some differences. The same three characteristics are rated highest by both groups, and recelve very few ratings as lowest from either group: salary, opportunity for advancement, and intellectual challenge, ${ }^{13}$ though men do opt more often for the first two, women for the third. ${ }^{14}$ Also, there are no differences by gender in the five characteristics that recelve 
the lowest ratings: earning acclaim, fringe benefits, not too demanding, opportunity to travel, and flexible hours. Women, however give more low rankings to earning acclaim; men more to opportunity to trave1.

Certaln aspects of these findings provide modest support for some aspects of traditional views of women's and men's preferences. The greater 1mportance wen attach to salary, opportuntty, advancement and Job security, as well as women's greater emphasis on work environment and, to a lesser extent, on pleasant co-workers, are in 11ne with generally accepted perceptions of gender differences. On the other hand, women's greater concern with having a challenging fob, but not with being close to family, pleasant geographic location, or flexible hours is contrary to thew. The substantial sidilarities between the women and men in this sample are less surprising when it is kept in mind that they chose a relatively exacting and nontraditional career path, and that earlier studies (e.g., Diploy, 1987; Ferber and Green, 1989) also found that wowen and men among successful managers differed considerably less than among other workers.

These descriptive data tell us a good deal about the background, plans, and expectations of the members of the sample. In the next section we turn to the central 1 ssue of this paper, an examination of the relationship between planned labor force participation and expected earnings, in order to shed further light on explanations of the male-female earnings gap. 


\section{Testing the Hypotheses}

Given our data on plans and expectations, we are able to test the human capltal hypothesis of women's lower earnings. We also examine whether there are feedback effects of expectations of lower earnings on women's work plans. Again, we focus upon the salarles which students expect to earn in their preferred occupation if they were to work continuously after leaving school. The dependent varlables are the natural logs of expected salaries at the beginning of the career, and 10 and 20 years later. The models are estimated for the total sample and for women and men separately in order to Investigate the extent of gender differences in coefficients.

To test the human capital hypothesis that planned labor force participation w11l Influence expected earnings profiles, number of years the respondents planned to work full-time is entered in the regression. 15 All else equal, it is expected that individuals who anticipate shorter work 11 ves will select jobs with flatter earnings profiles. Thus, years of planned full-time work are expected to be 1nversely related to beginning salaries and positively related to salaries 10 and 20 years later. Priorities given to varlous grouplngs of job characteristics are also introduced, in order to determine whether differences in tastes have any effect on earnings. 16 These 1tems are added to the more usual variables of college major, GPA and sex. 17

The results of the three regressions are seen In Table 5. (Means and standard deviations of the varlables for the regression sample are shown in Appendix Table A-2). Overall, we find no significant gender 
differences in expected starting salaries, ceteris paribus. These results are similar to those shown in Table 2, where other variables were not accounted for, and in Table 3, where expected salaries were shown for each of nine occupations. However, as is the case for the unadjusted gender differentials, men expect considerably higher salaries in later years. Sex is significant at the 1 percent level in these regressions, with men expecting approximately 18 percent higher salarles than women 10 years after graduation and 26 percent higher Balaries 20 years 1 ater, all else equal. These differences are large relative to the unadjusted gender differentials in the log of earnings of .236 and .322 , respectively. Thus, the steeper earnings profiles which men anticipate for continuous employment do not appear to be explained to any great extent by gender differences in expected labor market experience, work priorities, or the other variables included in the regression.

Contrary to the predictions of human capital theory, expected labor force participation has no significant effect on expected earnings in any of the regressions. We do not find expected beginning salaries to be higher for those who plan to spend less time in the labor force. Nor does greater planned labor force attachment have a slgniflcant positive effect on expected salaries in later years. Varying priorities for different job attributes also have little or no effect for either men or women. Placing a high priority on salary does appear to have a significant positive effect on expected beginning salaries. Also, placing importance on the job being not too demanding significantly reduces expected beginning salarles as well as 
those 20 years later. However, it may be recalled that this job characteristic is regarded as just about equally unimportant by women and men. Hence we conclude that at least in this admittedly selected sample of young people such differences in tastes as do exist do not help to explain why men expect higher earnings than women in later years.

An examination of the separate regressions for women and men points toward higher expected returns for GPA in later years giving men the advantage, and suggests that they have greater confidence in obtaining raises, and presumably promotions, in return for better performance. $^{18}$ The crucial question, which our data do not enable us to answer, is to what extent these different expectations are real1stic.

In view of the possibility that men's steeper earnings profiles may be related to different occupations selected or to further schooling, we also ran regressions with these variables added. The coefficients for them were not significant, and the explanatory power of the regressions remained essentially the same. Hence there is no evidence here that these varlables influence earnings, after controlling for college major and the other variables.

One problem with the approach used so far is the 1mp1icit assumption that labor force participation plans are exogenous, although a more general theory would suggest that they are $11 \mathrm{kely}$ to be made simultaneously with other career decisions. Even though the bias of the oLs regression 1 s $11 k e l y$ to overestimate rather than to understate the effect of work plans, we therefore estimate a two-equation model 
using two-stage least squares, which takes into account the interdependence of planned labor force participation and earnings expecta19

Virtually all the men anticipate working continuously until retirement (except for withdrawals for full-time schooling). Therefore, these relationships are examined only for the women. We focus on salary 20 years after graduation, because that is where the largest difference in expected earnings between women and men is obtained. The determinants of number of years of planned ful1-time work 1nclude, In addition to expected salary 20 years after graduation, the number of children the woman expects to have as a measure of the anticipated value of home time; grade point average as a proxy for ability, and three background variables, father's and mother's occupation, and the proportion of years the respondent's mother spent in the labor market, as determinants of the daughter's career-orientation and taste for market work. 20

The results are shown in Table 6 . Note that the sample size 18 reduced for these estimates due to missing values on the additional variables included in the model as determinants of planned work experience. (Means and standard deviations of the variables are shown in Appendix Table A-3.) The results again give 11ttle support to the human capital explanation of the earnings gap in that number of years of expected full-time employment does not influence expected earnings. On the other hand, the results also do not lend support to the proposition that women's lower earnings produce feedback effects causing them to reduce their labor force participation in that 
expected salary does not significarity affect planned full-time work. They do, however, provide some evidence on the other determinants of labor force participation plans.

Predictably, children have a negative effect. Each additional child reduces women's planned full-time work by 1.82 years. Thus, at the mean expected number of children, 2.4, full-time work is reduced by 4.37 years. Also of interest is the influence of parents' occupational status, and of the amount of time the mother was employed, clearly suggesting that the labor force participation plans of these women are, at least in part, determined by family background. Beyond that, the relevance of mother's status has 1mportant implications about the effect of current changes in women's labor force participation on future developments: Women's rapidly changing occupational and employment status may be expected to provide continued impetus for their daughters to move further in the same direction. It may seem surprising that a high occupational status of the father has a negative effect on women's work plans, all else equal. However, since husband's earnings are inversely related to women's labor force participation, this finding may plausibly be interpreted as indicating that these young women anticlpate marrying a man with similar earnings prospects to their father.

\section{Conclusion}

Because young people make decisions about jobs and careers on the basis of expectations, information based on outcomes is suggestive but not conclusive for testing hypotheses about the way labor force participation influences earnings, or about the way earnings influence 
labor force particlpation. Therefore, we collected data on work plans and anticipated earnings of college business school sentors that enable us to avold this difficulty. They were chosen because they are likely to be relatively knowledgeable and career orlented and hence would be likely to have made plans and formulated expectations. Further, the women in this group represent a cohort that is particularly 1mportant because they are among the vanguard who are forging ahead in the labor market in a way that increasingly more women want to emulate.

We found that, a11 else equal, women expect to earn about as much as men at the beginning of their careers, but not later on. Although women did anticlpate shorter work lives than men, we found no effect of planned labor force participation on expected earninge profiles. Th1s does not mean actual earnings would not be influenced by actual interruptions. It does, however, show that expected returns to experience for continuous employment are not significantly different In jobs chosen by those who plan to spend different amounts of time in pald work. Thus, we st111 have no adequate explanation for the full extent of women's lower expected earnings in later years for this group of young women.

At the same time, these findings are consistent with the interpretation that while these women do not expect to be discriminated against at the time they look for their first job, they anticipate that they will do less well in terms of promotions. Such a perception may be based on the fact that the male-female earnings gap actually increases with age, and on the belief of the respondents that this is 
the case even when there are no differences in qualifications and tastes. This study does not shed any $11 \mathrm{ght}$ on the question of whether this belief is justified or whether these lower expectations may cause women to settle for lower salarles without striving as hard as would men who have higher expectations. Such speculations recelve some support from a recent study of college students by Sublch et al. (1989) which found clear evidence that men were more wl111ng to take risks, as well as more equivocal evidence that they were more confident. Our study does, however, provide evidence that it is not lower expected earnings that cause women to spend less time in the labor market, and, to that extent, militates against the 1mportance of such feedback effects for this group.

The results of this study clearly have potential policy implications. On the one hand, to the extent the expectations of these students are realistic, they provide no reason to be complacent about equal opportunity having been achleved by women, not even young, wel1educated career-oriented women. They no longer expect to encounter difficulties in getting in the door, but that does not mean that the same is true for the portals to the executive suite. Continued efforts on the part of government, business, and individuals to ensure equal rewards for equal qualifications would therefore still be desirable. On the other hand, our findings suggest that Increasing the earnings of these women further may not have much influence on their allocation of time between household and employment.

Parenting is by far the dominant reason why many of these women plan to reduce their labor force participation. It 1s, of course, 
entirely possible that other factors, not considered in this study, such as soclal pressures and the avallabillty of high-quallty and convenfent child care, are also 1mportant. If so, government action, which can, to a greater or lesser degree, set the tone and establish standards, both through tes own actions and by Influencing employer policles could make a difference. Even in the absence of such pol1cles, however, our findings suggest that the greater labor force particlpation of women whose daughters are now reaching adulthood set the stage for the further changes in labor force attachment of the next generation, which 1n turn may be expected to reduce resistance to promoting women to positions of responsibility. 
1 A good deal of the emphasis in this work is on explaining occupational segregation, but our investigation touches on this subject only tangentially.

2

It is generally simply assumed that women, but not men, have household responsibilities. Becker (1981) attributes this division of labor to comparative advantage. But that, in turn, raises the question of why women would have a relative advantage in homenaking. These 1ssues are clearly beyond the scope of this paper. We merely want to point out that they are fundamental to any hypothesis that begins with differences in male and female labor force attachment.

\section{3} Human capital theory also suggests that a person who does not
plan to work continuously has less incentive to invest in formal human capital, say by acquiring schooling, because there would be fewer years to collect the additional returns. Since the members of our sample, to be described later, all have the same amount of education, we are in no position to address this issue.

4

4 An empirical study by Bielby and Bielby (1985) does not support the Becker view. They find that women actually put more effort into paid work than do men, though their conclusion is based on selfreported data.

${ }^{5}$ Sandell and Shapiro (1980) and Shaw and Shapiro (1987), using NLS panel data give partial support to the human capital explanation. Both studies find that planning to work yielded a substantial wage advantage, but Shaw and Shapiro showed no evidence of greater returns to work experience. Their data, in any case, have some shortcomings for this purpose. Among their limitations is the fact that the respondents are only asked whether they expect to be working at age 35 , not how many years they plan to be in the labor force.

${ }^{6}$ Gronau (1988) uses expectations data in his recent research. He emphasizes the importance of skill requirements as an explanation of earnings differentials. Not only is the skill intensity in men's jobs high, but it is strongly related to thelr labor force experience, while it is far lower in women's jobs, independent of their work plans, and only slightly related to experience. Gronau concludes that his findings lend support to the existence of wage discrimination through occupational segregation, and that women face restrictions on their job choice.

${ }^{7}$ Shaw and Shapiro (1987), found that young women tended to underestimate the extent to which they would be employed at age 35 . We shall return to this point later. 
8

We did not ask for 1nformation about race and ethnicity because only about 5 percent of the students in CBA are blacks or other minorities.

9 At

9 At this University students have the option of belng Economics majors 1n the College of Liberal Arts and Sciences, as well as $1 \mathrm{n}$ the College of Business Administration, and substantial numbers of Liberal Arts students select this major.

10

Anticlpated years of full-time schooling account for most of the t1me men plan to be out of the work force, while time spent 1n fullt1me parenting accounts for the bulk of women's expected time out of the labor market.

11

An open-ended question asked about the job respondents hoped to get upon graduation. We found that of the 217 women and 156 men who answered that question 182 and 113 respectively named the one they gave first preference among the 10 options 11 sted. Of the others, 17 women and 21 men planned to become attorneys.

12 Data comparing students' expected salaries to actual salaries are presented in Appendix $B$. We find that both men and women tended to overestimate salaries as compared to prevalent ones. Similar findlings are reported for American college students by Subich et. al. (1989). On the other hand, a British study (W11liams and Gordon, 1981) found that student's expectations were accurate.

13 Lest there be concern that these cholces were influenced by the presentation of the questions, 1t should be noted that they were not grouped in the questionnalre.

14.

Anderson and Anderson (1988) similarly found that women as compared to men are more interested in a "feeling of accomplishment," and in "Interesting work," and less concerned with "money."

15

Using total number of years students expected to be 1n the 1 abor force Instead did not change the outcome. When number of years students expected to work part-time was entered separately, the coefflclent was not significant.

16

Preferences for particular characteristics of the job were grouped as shown In Table 4, except that those In the "other" category were omitted. Using them did not add to the explanatory power of the regressions. The ones 1ncluded were expressed as an 1ndex: 3 - any ranked f1rst; 2 = any ranked second; 1 = any ranked th1rd; -1 - any ranked thirteenth; -2 = any ranked fourteenth; $-3=$ any ranked fifteenth. Specifying these variables as dummles produced similar results regarding thelr 1mpact on gender differences in earnings. 
${ }^{17}$ Unlike Gronau (1988), we have no 1nformation on skill requirements for jobs, which he found to be very important in determining wages. He also found, however, that there were no significant differences in this respect between female and male professional and technical workers, which covers all the occupations used in this study except management trainees.

${ }^{18}$ Twenty years after graduation, when the earnings differential is largest, the difference in returns to GPA evaluated at the overall sample mean (which is virtually the same for men and women) is 0.596 . This is more than sufficient to account for the gross gender difference in expected earnings of 0.322 . (Differences in the constant term actually favor women.) These findings are reminiscent of those in Ferber and Green (1989) which showed that the reward structure of a sample of individuals self-identified as "top management" provided virtually no evidence that differences in human capital characteristics had any effect on women's earnings, though they influenced those of men.

${ }^{19}$ In view of the crucial role atrophy plays in human capital theory (Polachek, 1981), we also ran a set of two stage regressions using that variable instead of expected salary, but found that we were singularly unsuccessful in explaining atrophy, and that 1 added nothing to the explanation of work plans. The atrophy rate was calculated by finding how much less these students expected to earn 10 years after leaving school, if they were to drop out of the labor market for years $5-9$, as compared to working continuously during the whole period.

${ }^{20}$ The instruments in the first-stage regressions included all the exogenous variables in both the planned full-time work and expected salary equations. Since number of children may be viewed as, at least in part, endogenous, we also ran the same model excluding this variable from both the first- and second-stage regressions. The $R^{2}$ was somewhat lower for years worked, and somewhat higher for salary, but the same variables remained significant. 


\section{B1b1lography}

Anderson, Robert L. and Kathleen P. Anderson, "A Comparison of Women In Sma11 and Large Compantes," American Journal of Small Business, Vo1. 12, No. 3 (Winter 1988): 23-33.

Applebaum, E1leen and Ross Koppe1, "The Impact of Work Attitudes Formed Prior to Labor Market Entry on the Process of Early Labor Market Attainment," In Paul J. Andrisan1, E1leen Applebaum, Ross Koppe1, and Robert Milfins, eds., Work Att1tudes and Labor Market Experience, NY: Praeger Publishers, 1978.

Becker, Gary S., A Treat1se on the Family, Cambridge, MA: Harvard University Press, 1981.

Becker, Gary S., "The Allocation of Effort, Specific Human Capital, and the Differences Between Men and Women In Earninga and Occupat lons," Journal of Labor Economics, Vo1. 3, No. 1, Pt. 2 (Jan. 1985): 533-58.

Becker, Gary S., The Economics of Discrimination, Chicago, University of Chicago Press, 1957.

Bielby, Denise D. and William T. Bielby, "She Works Hard for the Money: Household Responsibilities and the Allocation of Effort." Paper presented at the Aug. 1985 meetings of the American Statistical Association.

Blau, Francine D. and Marlanne A. Ferber. The Economics of Women, Men and Work, Englewood Cliffs, NJ: Prentice-Hall, 1986.

Corcoran, Mary, Greg J. Duncan and Michsel Ponza, "Work Experience, Job Segregation, and Wages," In Barbara F. Reskin, ed., Sex Segregation in the Workplace: Trends, Explanations, Remedies, Wash1ngton, D.C.: National Academy Press, 1984, pp. 171-91.

Daymont, Thomas N. and Paul J. Andrtsant, "Why Women Earn Less Than Men: The Case of Recent College Graduates," IRRA 35th Annual Proceedings, 1988: 425-35.

Diploy, Robert L., "Problems and Progresa of Women in Management," in Karen S. Kozlara, Michael H. Moskov and Lucretia D. Tanner, eds., Working Women: Past, Present, Future, Industrial Relations Research Association Serles, Washington, D.C.: The Bureau of Nationa 1 Affairs, Inc., 1987.

England, Paula, "The Failure of Human Capital Theory to Explain Occupational Sex Segregation," Journal of Human Resources, Vol. 17 , No. 3 (Summer 1982): $358-70$. 
Ferber, Marlanne A. and Carole A. Green, "Occupational Segregation and the Earnings Gap: Further Evidence," unpublished, 1989.

Filer, Randall K., "Male-Female Wage Differences: The Importance of Compensating Differentials," Industrial and Labor Relations Review, Vol. 38, No. 3 (Apr. 1985): 426-37.

Gronau, Reuben, "Sex-related Wage Differentlals and Women's Interrupted Labor Careers-the Chicken or the Egg," Journal of Labor Economics, Vol. 6, No. 3 (July 1988): 277-301.

Miller, Herman P., "Lifetime Income and Economic Growth," American Economic Review, Vol. 55, No. 4 (Sept. 1965): 834-44.

Mincer, Jacob and Solomon W. Polachek, "Family Investments in Human Capital: Earnings of Women," Journal of Political Economy, Vol. 82, No. 2, Pt. 2(Mar.-Apr. 1974): S76-S108.

Polachek, Solomon W., "Differences in Expected Post-School Investment as a Determinant of Market Wage Differentials," International Economic Review, 16, 2 (June 1975): 451-70.

Polachek, Solomon W., "Occupational Self-Selection: A Human Cap1tal Approach to Sex Differences in Occupational Structure," Review of Economics and Statistics, Vol. 63, No. 1 (Feb. 1981): 60-69.

Sande11, Steven H., and DavId Shap1ro, "Work Expectations, Human Capital Accumulation, and the Wages of Young Women," Journal of Human Resources, Vol. 15, No. 3 (Summer 1980): 335-53.

Shaw, Lo1s B. and David Shaplro, "Women's Work Plans: Contrasting Actual Expectations and Actual Work Experience," Monthly Labor Revlew, Vol. 110, No. 11 (Nov. 1987): 7-14.

Smith, James P. and Michael P. Ward, Women's Wages and Work in the Twent1eth Century, Santa Monfca, $\overline{\mathrm{CA}}$ : Rand, 1984.

Sublch, Linda Mezydlo, Gerald V. Barrett, Dennls Doveraplke, and Ralph A. Alexander, "The Effects of Sex-Role-Related Factors on Occupational Cholce and Salary" in Robert T. Mlchael, Heldi I. Hartmann, and Brigld O'Parrell, eds., lay Equlty: Emplrical Inquirles, Washington, DC: National Acndemy Press, 1989.

U.S. Department of Commerce, Bureau of the Census, Male-Female Differences in Work Experience, Occupation and Earnlngs, 1984, Wash1ngton, D.C., 1987.

U.S. Department of Commerce, Bureau of the Census, Fertility of Women in America: June 1987, Current Population Reports, Series P-20, No. 427, Washington, D.C., May 1988. 
We1ss, Yoram and Reuben Gronau, "Expected Interruptions in Labor Force Participation and Sex-Related Differences in Earnings Growth," Review of Economic Studies, Vol. 48, No. 4 (October 1981): 607-19.

Williams, G. and A. Gordon, "Percelved Earnings Functions and Ex Ante Rates of Return in Past Compulsory Education in England," Higher Education, Vol. 10, No. 2 (March 1981): 199-227. 
Table 1

Background Information for Sample Members

(sample sizes in parentheses)

\begin{tabular}{lcc} 
& $\frac{\text { Women }}{(227)}$ & $\frac{\text { Men }}{(161)}$ \\
Department $^{a}$ & & \\
\hline $\begin{array}{l}\text { Accountancy } \\
\text { Business Administration }\end{array}$ & 30.0 & 34.8 \\
Econom1cs & 40.1 & 24.8 \\
F1nance & 2.2 & 3.7 \\
N.A. & 26.9 & 36.7 \\
Tota1 & 0.9 & 0.0 \\
Grade Point Average & 100.0 & 100.0 \\
& 4.3 & 4.3 \\
Mean Age & $(227)$ & $(161)$ \\
& 21.6 & 21.8 \\
& $(227)$ & $(159)$
\end{tabular}

Family Plans

Plan to be married

94.0

(217)

92.1

(\%)

2.4

(152)

Mean number of

children planned

(194)

2.8

(124)

Mother's Work Status
Proportion of years in the
43.8
40.8
labor force (\%)
(225)
(157)

\begin{tabular}{|c|c|c|c|c|}
\hline \multirow[b]{2}{*}{ Parents Occupations ${ }^{a}$} & \multicolumn{2}{|c|}{ Women } & \multicolumn{2}{|c|}{ Men } \\
\hline & $\frac{\text { Mother }}{(226)}$ & $\frac{\text { Father }}{(222)}$ & $\frac{\text { Mother }}{(159)}$ & $\frac{\text { Father }}{(155)}$ \\
\hline $\begin{array}{l}\text { Executive } \\
\text { Professional \& }\end{array}$ & 12.0 & 25.7 & 4.4 & 29.0 \\
\hline $\begin{array}{l}\text { technical } \\
\text { Sales } \\
\text { Clertcal }\end{array}$ & $\begin{array}{r}23.5 \\
5.8 \\
22.1\end{array}$ & $\begin{array}{r}27.9 \\
9.5 \\
3.2\end{array}$ & $\begin{array}{r}18.9 \\
6.3 \\
18.9\end{array}$ & $\begin{array}{r}28.4 \\
10.3 \\
0.0\end{array}$ \\
\hline $\begin{array}{l}\text { Blue collar } \\
\text { 0ther } \\
\text { Homemaker }\end{array}$ & $\begin{array}{r}2.7 \\
4.0 \\
28.3\end{array}$ & $\begin{array}{r}10.8 \\
14.9 \\
0.0\end{array}$ & $\begin{array}{r}3.1 \\
8.2 \\
36.5\end{array}$ & $\begin{array}{r}15.5 \\
6.5 \\
0.0\end{array}$ \\
\hline $\begin{array}{l}\text { Retired } \\
\text { Total }\end{array}$ & $\begin{array}{r}1.8 \\
100.0\end{array}$ & $\begin{array}{r}8.1 \\
100.0\end{array}$ & $\begin{array}{r}3.8 \\
100.0\end{array}$ & $\begin{array}{r}10.3 \\
100.0\end{array}$ \\
\hline
\end{tabular}

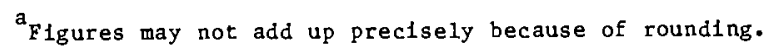


Table 2

Career Plans and Salary Expectations

\section{Labor Force Partcipation Plans}

\begin{tabular}{lrr} 
& $\begin{array}{c}\text { Women } \\
(218)\end{array}$ & \multicolumn{1}{c}{$\begin{array}{c}\text { Men } \\
(157)\end{array}$} \\
Mean number of years work full-time & 29.1 & 37.7 \\
Mean number of years work part-time & 6.2 & 1.2 \\
Mean number of years retired before 2038 & 9.1 & 9.6 \\
Mean number of years out of labor force & & \\
before retirement & 5.6 & 1.5
\end{tabular}

Flrst Choice Among 10 Most Usual Occupations

\section{Accountant}

Management trainee

$27.7 \% \quad 30.4 \%$

Financial/credit analyst

26.3

23.6

Sales representative or Insurance agent

15.2

23.6

Personnel/labor relations spectalist

3.1

4.3

Purchasing agent

5.4

3.7

Marketing analyst

3.1

0.6

Systems analyst

11.2

5.6

Real estate broker

1.8

2.5

Commerclal loan officer

1.3

1.2

4.94 .3

\begin{tabular}{lrr}
\multicolumn{1}{c}{$\begin{array}{cr}\text { Expected Salary } \\
\text { (1987 Do11ars) }\end{array}$} & \\
& $(203)$ & $(148)$ \\
Beginning & 23,327 & 23,983 \\
Ten years after graduation & 44,063 & 55,793 \\
Twenty years after graduation & 67,076 & 92,561
\end{tabular}

${ }^{a}$ Geometric means. Assumes continuous employment after leaving school. 
Table 3

Female/Male Ratios of Expected and Projected Actual Salaries ${ }^{a}$ (1987 Dollars)

\begin{tabular}{|c|c|c|c|c|}
\hline & & Beg1nning & $\begin{array}{c}\text { Ten } \\
\text { Years } \\
\text { Later }\end{array}$ & $\begin{array}{r}\text { Twenty } \\
\text { Years } \\
\text { Later }\end{array}$ \\
\hline Accountants: & $\begin{array}{l}\text { Expected } \\
\text { Actual }\end{array}$ & $\begin{array}{l}98.8 \\
99.4\end{array}$ & $\begin{array}{l}78.4 \\
71.2\end{array}$ & $\begin{array}{l}76.1 \\
67.7\end{array}$ \\
\hline Managers: & $\begin{array}{l}\text { Expected } \\
\text { Actual }\end{array}$ & $\begin{array}{l}96.0 \\
95.0\end{array}$ & $\begin{array}{l}77.3 \\
73.1\end{array}$ & $\begin{array}{l}67.4 \\
61.4\end{array}$ \\
\hline Financlal/credit analyst: & $\begin{array}{l}\text { Expected } \\
\text { Actual }\end{array}$ & $\begin{array}{l}97.3 \\
94.8\end{array}$ & $\begin{array}{l}82.8 \\
72.2\end{array}$ & $\begin{array}{l}68.8 \\
56.5\end{array}$ \\
\hline $\begin{array}{l}\text { Sales representatives, } \\
\text { insurance agents: }\end{array}$ & $\begin{array}{l}\text { Expected } \\
\text { Actual }\end{array}$ & $\begin{array}{r}100.2 \\
96.2\end{array}$ & $\begin{array}{l}88.3 \\
81.3\end{array}$ & $\begin{array}{l}82.8 \\
65.8\end{array}$ \\
\hline $\begin{array}{l}\text { Personnel and labor } \\
\text { relations speclalists: }\end{array}$ & $\begin{array}{l}\text { Expected } \\
\text { Actual }\end{array}$ & $\begin{array}{l}83.5 \\
86.3\end{array}$ & $\begin{array}{l}88.8 \\
71.2\end{array}$ & $\begin{array}{l}84.0 \\
63.0\end{array}$ \\
\hline Purchasing agents: & $\begin{array}{l}\text { Expected } \\
\text { Actual }\end{array}$ & $\begin{array}{l}98.9 \\
\text { n.a. }\end{array}$ & $\begin{array}{l}86.0 \\
\text { n.a. }\end{array}$ & $\begin{array}{l}91.0 \\
\text { n.a. }\end{array}$ \\
\hline Marketing analysts: & $\begin{array}{l}\text { Expected } \\
\text { Actual }\end{array}$ & $\begin{array}{l}93.1 \\
96.6\end{array}$ & $\begin{array}{l}80.8 \\
80.8\end{array}$ & $\begin{array}{l}80.0 \\
78.5\end{array}$ \\
\hline Systems analyots: & $\begin{array}{l}\text { Expected } \\
\text { Actual }\end{array}$ & $\begin{array}{l}91.6 \\
95.8\end{array}$ & $\begin{array}{l}84.4 \\
90.7\end{array}$ & $\begin{array}{l}91.2 \\
86.2\end{array}$ \\
\hline Real estate brokers: & $\begin{array}{l}\text { Expected } \\
\text { Actual }\end{array}$ & $\begin{array}{l}97.3 \\
96.6\end{array}$ & $\begin{array}{r}100.6 \\
82.5\end{array}$ & $\begin{array}{l}71.0 \\
70.3\end{array}$ \\
\hline
\end{tabular}

axpected salaries assume continuous employment after leaving school. Actual salaries are projected based on data for beginning salaries and estimated growth rates based on Census data on earnings by age and sex for year-round, ful1-time workers (see Append1x B). 
Table 4

\section{Proportion of Respondents Ranking Job Characteristics Among} H1ghest and Lowest Three Priorities

\begin{tabular}{|c|c|c|c|c|}
\hline & & & & \\
\hline & $\underline{\mathrm{H}} \underline{\mathrm{g}} \overline{\mathrm{h}}$ & Low & $\underline{\mathrm{H}} \mathbf{g h}$ & Low \\
\hline Salary & 52.4 & 4.6 & 67.5 & 4.5 \\
\hline Opportunity for advancerent & 58.7 & 1.4 & 65.0 & 1.3 \\
\hline $\begin{array}{l}\text { Challeng1ng job } \\
\text { Intellectual challenge } \\
\text { Independent/work autonomy }\end{array}$ & $\begin{array}{l}55.6 \\
19.6\end{array}$ & $\begin{array}{r}0.5 \\
10.6\end{array}$ & $\begin{array}{l}41.9 \\
11.9\end{array}$ & $\begin{array}{r}3.8 \\
11.5\end{array}$ \\
\hline $\begin{array}{l}\text { Pleasant environment } \\
\text { Near family } \\
\text { Work environment }\end{array}$ & $\begin{array}{r}8.9 \\
42.2\end{array}$ & $\begin{array}{r}19.3 \\
1.8\end{array}$ & $\begin{array}{l}11.9 \\
32.5\end{array}$ & $\begin{array}{r}22.3 \\
2.6\end{array}$ \\
\hline $\begin{array}{l}\text { Pleasant geographic location } \\
\text { Pleasant co-workers }\end{array}$ & $\begin{array}{r}6.2 \\
19.1\end{array}$ & $\begin{array}{r}15.1 \\
2.8\end{array}$ & $\begin{array}{l}11.3 \\
15.6\end{array}$ & $\begin{array}{r}17.8 \\
0.6\end{array}$ \\
\hline Not demanding & 1.8 & 75.2 & 0.0 & 76.4 \\
\hline Other & & & & \\
\hline $\begin{array}{l}\text { Making contribution to soclety } \\
\text { Earning acclaim } \\
\text { Fringe benefits }\end{array}$ & $\begin{array}{l}6.2 \\
2.2 \\
4.0\end{array}$ & $\begin{array}{l}28.4 \\
50.0 \\
11.9\end{array}$ & $\begin{array}{l}9.4 \\
2.5 \\
2.5\end{array}$ & $\begin{array}{l}26.1 \\
39.5 \\
10.2\end{array}$ \\
\hline $\begin{array}{l}\text { Job security } \\
\text { Opportunity to trave } 1 \\
\text { Flexible hours }\end{array}$ & $\begin{array}{r}13.8 \\
5.3 \\
2.2\end{array}$ & $\begin{array}{r}5.5 \\
38.5 \\
33.5\end{array}$ & $\begin{array}{r}23.8 \\
2.5 \\
1.9\end{array}$ & $\begin{array}{r}3.8 \\
47.1 \\
31.2\end{array}$ \\
\hline
\end{tabular}




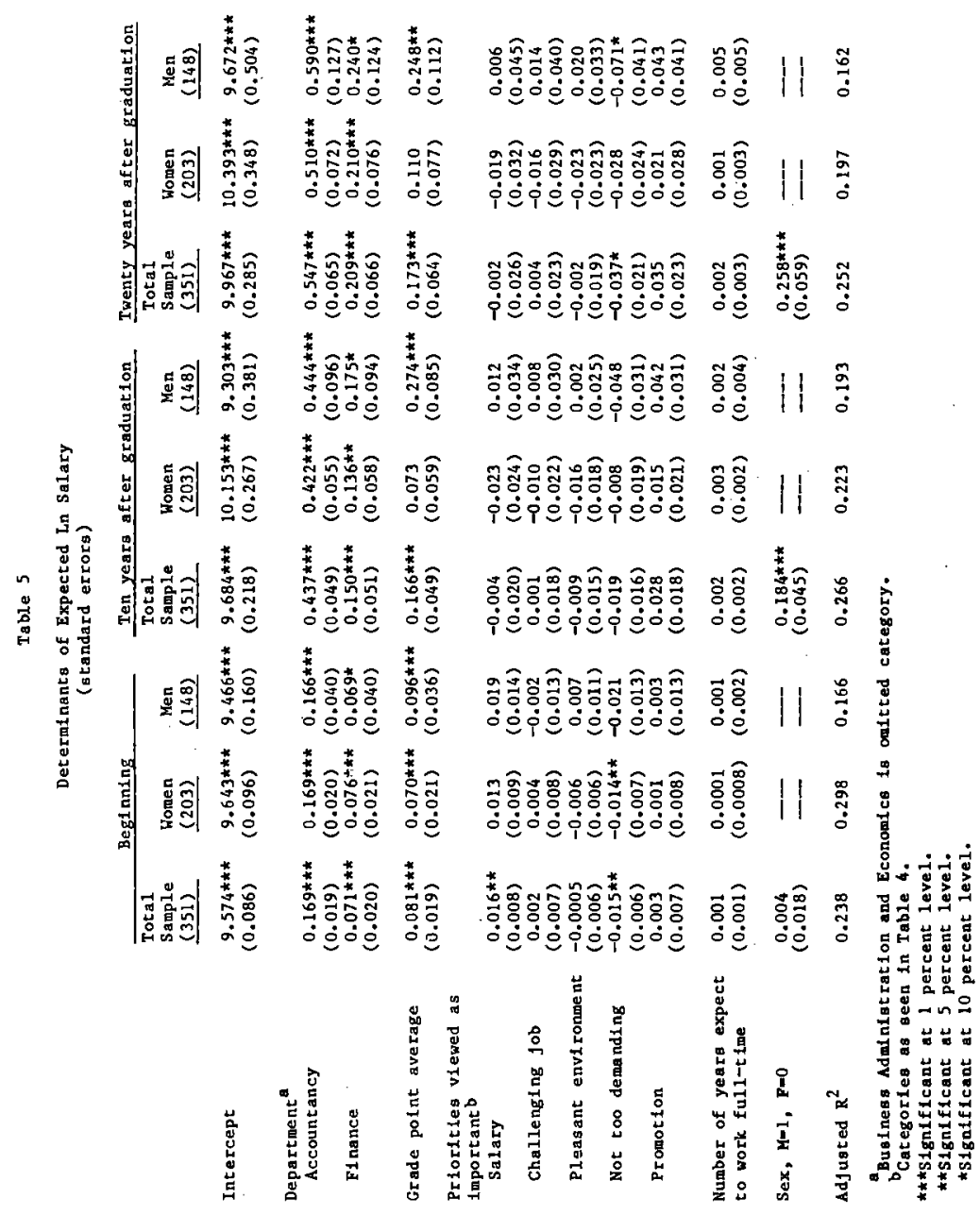


Table 6

Two-Stage Least Squares Results for Number of Years Women Plan to Work Full-Time and Ln Expected Salary Twenty Years After Graduation

$(n=170)$

Number of Years Plan to Work Full-Time

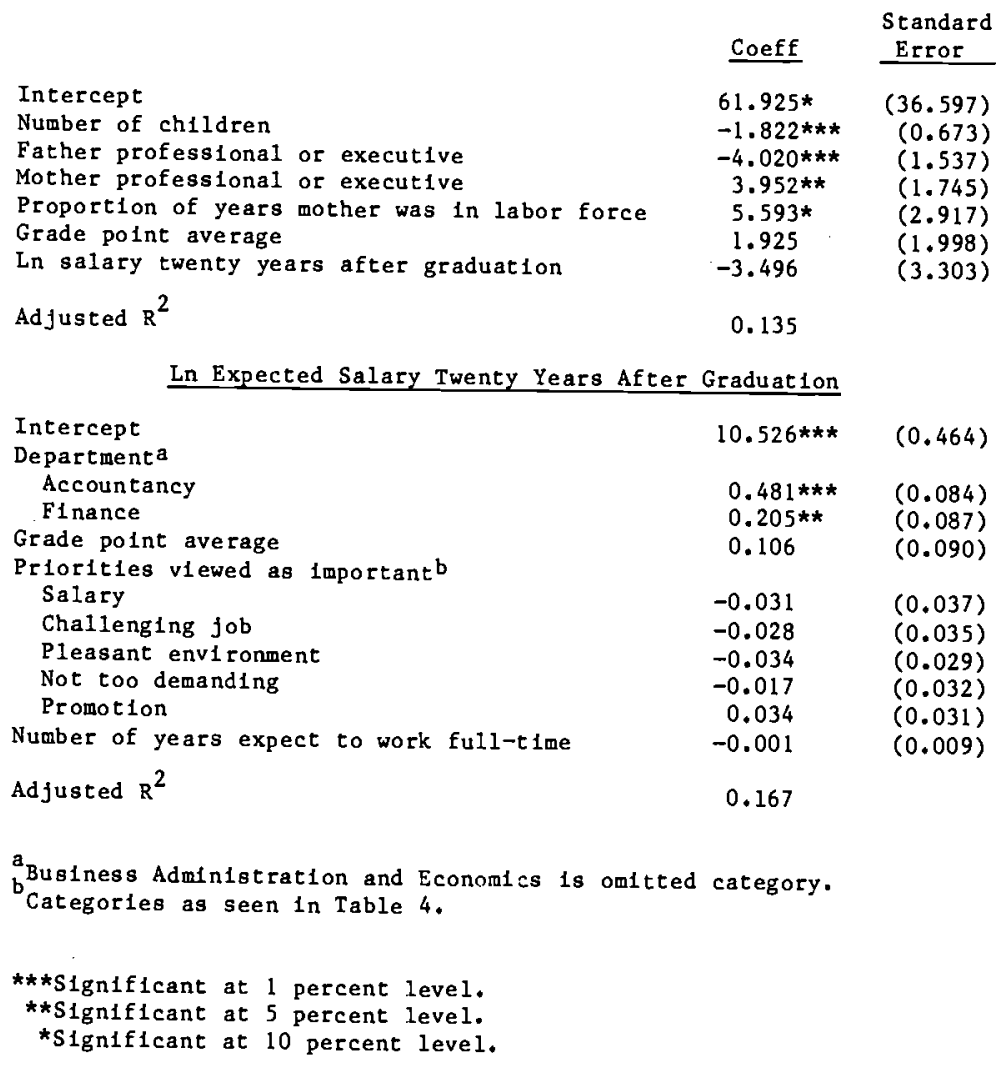


Table A-1

Background Information for Nonrespondents

$\frac{\text { Women }}{(162)} \quad \frac{\text { Men }}{(172)}$

Department

$(\%)$

Accountancy

32.5

32.0

Business Administration

38.6

20.9

Economics

0.0

2.9

Finance

25.9

42.4

N.A.

3.0

1.7

Total

100.0

100.0

Grade Polnt Average

4.3

4.2 
Table A-2

Means and Standard Deviations of Variables Used in Table 5

$\begin{array}{llc}\text { Total } & \text { Women } & \text { Men } \\ (351) & (203) & (148)\end{array}$

Department

\begin{tabular}{|c|c|c|c|}
\hline Accountancy & $\begin{array}{c}0.328 \\
(0.470)\end{array}$ & $\begin{array}{c}0.310 \\
(0.464)\end{array}$ & $\begin{array}{c}0.351 \\
(0.479)\end{array}$ \\
\hline F1nance & $\begin{array}{c}0.313 \\
(0.464)\end{array}$ & $\begin{array}{c}0.266 \\
(0.443)\end{array}$ & $\begin{array}{c}0.378 \\
(0.487)\end{array}$ \\
\hline $\begin{array}{l}\text { Grade point average } \\
\text { Priorlties viewed as 1mportant }\end{array}$ & $\begin{array}{c}4.319 \\
(0.417)\end{array}$ & $\begin{array}{c}4.330 \\
(0.393)\end{array}$ & $\begin{array}{c}4.304 \\
(0.449)\end{array}$ \\
\hline Salary & $\begin{array}{c}0.994 \\
(1.171)\end{array}$ & $\begin{array}{c}0.852 \\
(1.125)\end{array}$ & $\begin{array}{c}1.189 \\
(1.209)\end{array}$ \\
\hline Challeng1ng job & $\begin{array}{c}1.256 \\
(1.409)\end{array}$ & $\begin{array}{c}1.434 \\
(1.400)\end{array}$ & $\begin{array}{c}1.014 \\
(1.390)\end{array}$ \\
\hline Pleasant env1ronwent & $\begin{array}{c}1.028 \\
(1.688)\end{array}$ & $\begin{array}{c}1.143 \\
(1.693)\end{array}$ & $\begin{array}{c}0.872 \\
(1.675)\end{array}$ \\
\hline Not too demanding & $\begin{array}{l}-1.698 \\
(1.256)\end{array}$ & $\begin{array}{l}-1.680 \\
(1.298)\end{array}$ & $\begin{array}{l}-1.723 \\
(1.200)\end{array}$ \\
\hline Promotion & $\begin{array}{c}1.285 \\
(1.262)\end{array}$ & $\begin{array}{c}1.241 \\
(1.241)\end{array}$ & $\begin{array}{c}1.345 \\
(1.292)\end{array}$ \\
\hline Number of years expect to work full-time & $\begin{array}{l}32.886 \\
(11.023)\end{array}$ & $\begin{array}{l}29.256 \\
(10.814)\end{array}$ & $\begin{array}{l}37.865 \\
(9.243)\end{array}$ \\
\hline $\begin{array}{l}\text { In expected salary } \\
\text { Beglnning }\end{array}$ & $\begin{array}{l}10.069 \\
(0.167)\end{array}$ & $\begin{array}{l}10.057 \\
(0.139)\end{array}$ & $\begin{array}{l}10.085 \\
(0.200)\end{array}$ \\
\hline Ten years later & $\begin{array}{l}10.793 \\
(0.434)\end{array}$ & $\begin{array}{l}10.693 \\
(0.365)\end{array}$ & $\begin{array}{l}10.929 \\
(0.482)\end{array}$ \\
\hline Twenty years later & $\begin{array}{l}11.249 \\
(0.562)\end{array}$ & $\begin{array}{l}11.114 \\
(0.469)\end{array}$ & $\begin{array}{l}11.436 \\
(0.625)\end{array}$ \\
\hline Sex, $M=1, F=0$ & $\begin{array}{c}0.422 \\
(0.495)\end{array}$ & -- & -- \\
\hline
\end{tabular}


Table A-3

Means and Standard Deviations of Varlables Used in Table 6 $(n=170)$

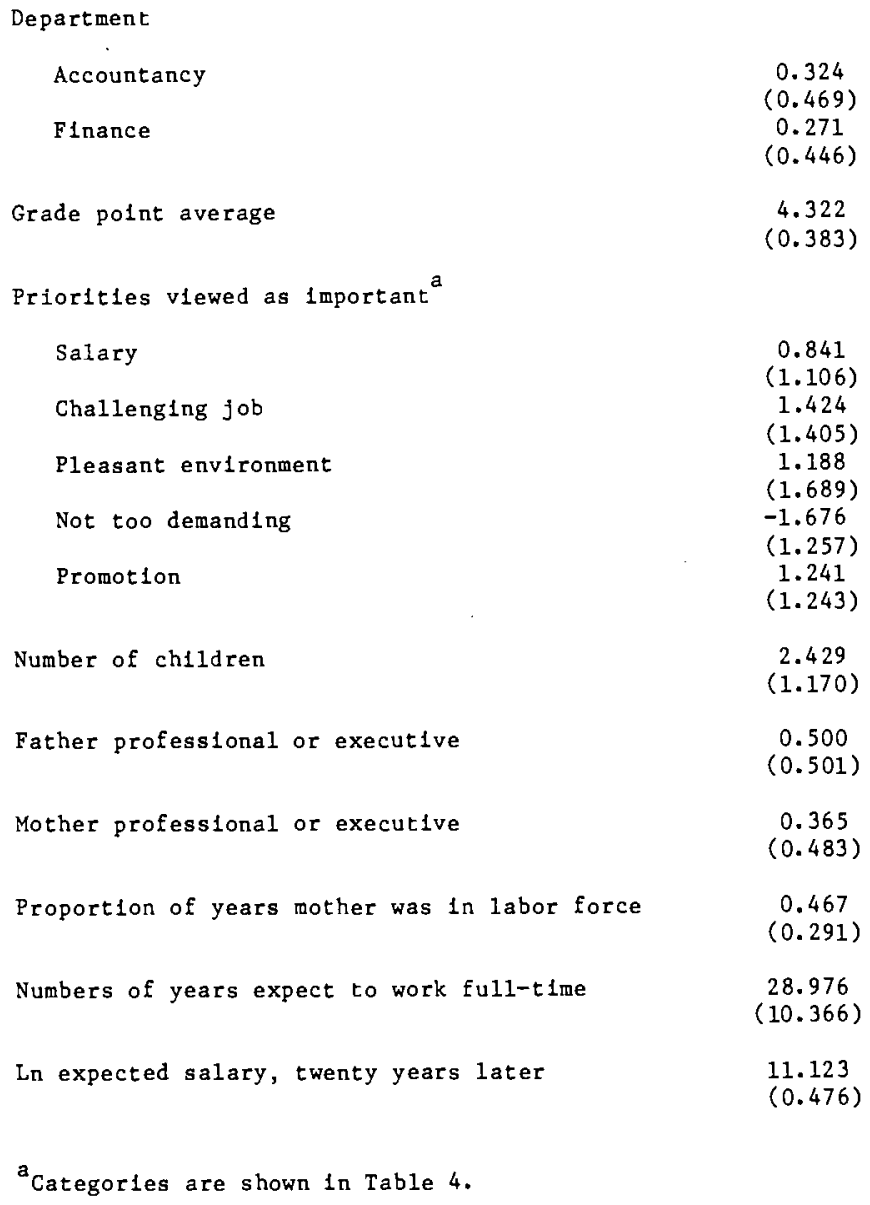

Father professional or executive

Mother professional or executive

Proportion of years mother was in labor force

Numbers of years expect to work full-time

Ln expected salary, twenty years later

${ }^{a}$ Categorles are shown in Table 4 . 


\section{Append 1x B}

Information on salaries students expect to earn in the jobs that are among their top three cholces if they were to work continuously after leaving school is offered in Table B-1, together with actual salarles offered to 1987 graduates for beginning earnings, and est 1mated salarles for 10 and 20 years later based on 1980 census data on earnings of workers 35-44 years and 45-55 years of age compared to workers 25-34 years old. This estimate is likely to understate women's earnings in subsequent years, since it assumes that continuously employed women will fare no better in terms of wage growth than women actually did in the past when many of them worked only Intermittently. Nonetheless, it gives us a rough estimate against which to compare women's salary expectations.

These data suggest that both men and women are rather optimistic about future earnings, but it must be noted that our projections Implicitly assume no overall increases in labor productivity. This seems realistic in view of the virtual absence of changes in real earnings in recent years, but it is also possible that the upward trend of earller years will resume to a greater or lesser degree. Miller (1965), for Instance, found that between 1949 and 1959 productivity rose by about 51 percent for workers aged 35-44, and 14 percent for workers 45 to 54. Were we to return to this upward trend, the unwelghted mean of earnings for wen in the elght occupations would be $\$ 49,294$ ten years after graduation and $\$ 63,200$ twenty years later, as compared to $\$ 32,645$ and $\$ 36,714$, as we projected. These figures are 


\section{Append1x B $($ cont'd.)}

not as $f$ ar below the $\$ 55,625$ and $\$ 99,783$ men expect to earn. It may be too that students who are $11 k e 1 y$ to be aware of ralses in dollar terms tend to underestimate the extent to which they reflect inflation rather than merit ralses. Further, these students with a degree from a highly-regarded business school may be correct in expecting to earn more than the average college graduate. Finally, it is worth noting that expected salary ratlos by gender are roughly in line with est1mates based on projections of actual salaries (Table 3). The anticipated ratios are generally somewhat higher which is to be expected given the assumption of continuous employment. 


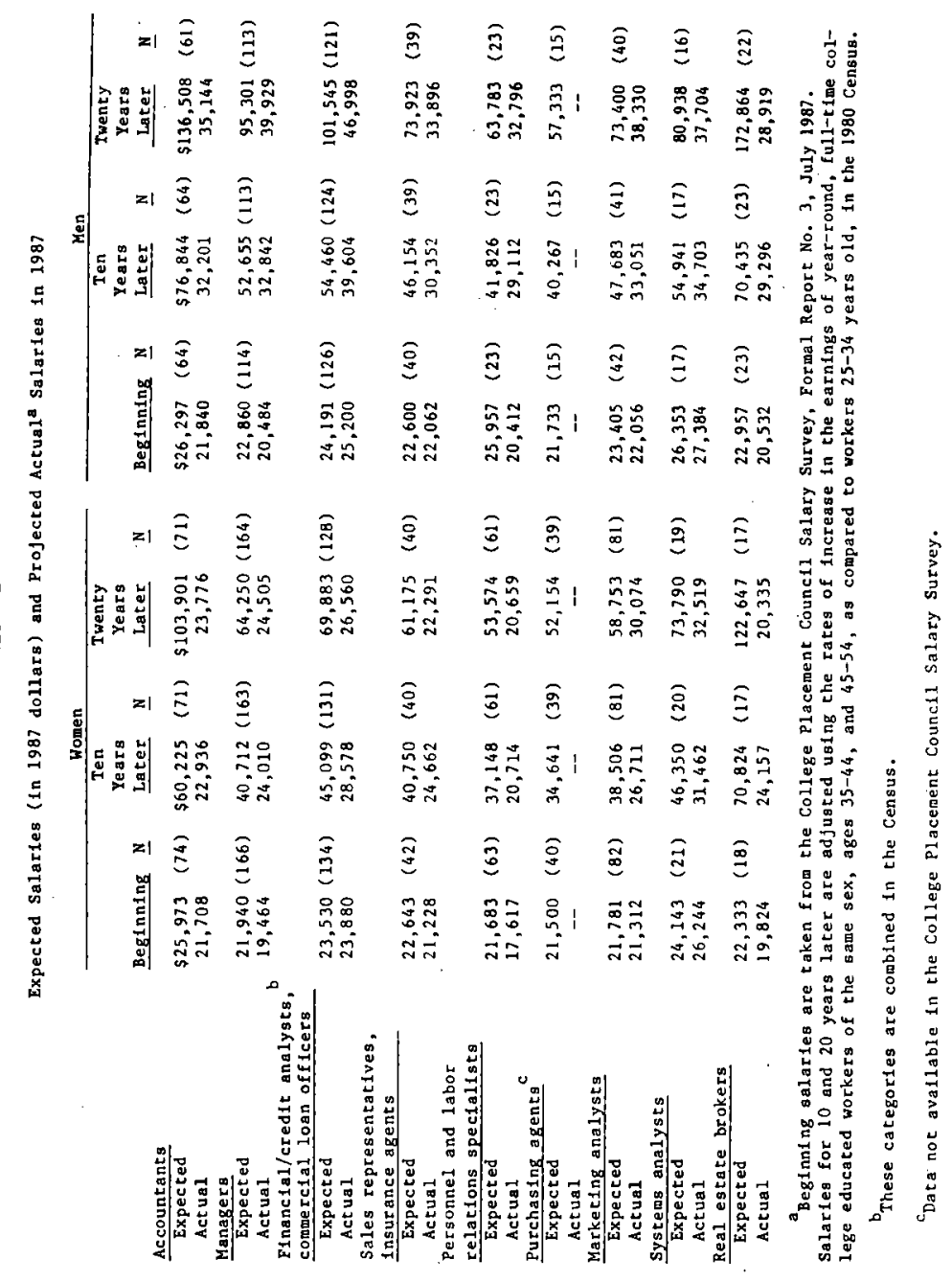

